\section{Temporal variation in the phytoplankton community of Acapulco Bay, Mexico}

\author{
Agustín A. Rojas-Herrera, \\ Juan Violante-González, \\ Sergio García-lbáñez, \\ Víctor M. G. Sevilla-Torres, \\ Jaime S. Gil-Guerrero, \\ Pedro Flores-Rodríguez
}

Unidad Académica de Ecología Marina, Universidad Autónoma de Guerrero, Acapulco, México

\section{Abstract}

Species composition and abundance of the phytoplankton community in Acapulco Bay, Mexico, were studied from May to December 2009. Samples were collected at 5 stations (4 coastal and one oceanic) at 3 depths (1,5 and $10 \mathrm{~m})$. Eighty-seven species were identified: 54 dinoflagellates, 32 diatoms and one silicoflagellate. The community was structured mainly by adiaphoric species, that is species adapted to both neritic and oceanic environments. Species abundance and composition varied significantly during the sampling period due to increased nutrient concentrations in the rainy season. Dinoflagellate species were more abundant during the dry season, and diatom species dominated numerically during the rainy season.

\section{Introduction}

Phytoplankton is one of the most complex communities in marine coastal environments. This community's structure is dictated by two important groups of organisms: i) non-motile, fast-growing diatoms; and ii) motile flagellates and dinoflagellates which can migrate vertically in the water column in response to light. All phytoplankton species are subject to water currents and have developed strategies for rapid nutrient absorption and fast reactions to fluctuations in hydrographic conditions. ${ }^{1}$ Thus, phytoplankton distribution and species composition are affected by several processes, including high water temperature, and variations in thermal stability and nutrient circulation.

Changes can occur in the taxonomic composition of phytoplankton communities, the total cell abundance and species richness during annual seasonal cycles. These changes reflect the capacity of communities to respond to seasonal variations in light, nutrient and circula- tion patterns. ${ }^{2}$ Under specific environmental conditions (e.g. high nutrient concentrations) these factors can cause some species to proliferate massively, causing harmful algal blooms (HAB) which can negatively affect marine communities. Of the more than 5,000 known marine phytoplankton species, approximately 40 species worldwide have been linked with the production of toxins. ${ }^{3-5}$

Santa Lucia Bay, also known as Acapulco Bay, is located on the tropical Pacific coast of southern Mexico, in Guerrero State. The bay has a semi-circular (6.3 km diameter), amphitheater-like shape created by low hills $(<500 \mathrm{~m})$ surrounding the south-facing bay. It is considered to be very climatologically protected (Agustín, unpublished data, 2011).

Research on marine phytoplankton communities abounds, ${ }^{6-9}$ but to date there have been no studies assessing the phytoplankton species composition in Acapulco Bay, Mexico. The aim of the present study was to document current species composition and abundance in the phytoplankton community of Acapulco Bay, and quantify any temporal variation in these variables.

\section{Materials and Methods}

Phytoplankton samples were collected in Acapulco Bay between May and December 2009 at 5 stations: i) Club de Yates $\left(16^{\circ} 50^{\prime} \mathrm{N}\right.$, $\left.99^{\circ} 54^{\prime} \mathrm{W}\right)$; ii) Islote del Morro $\left(16^{\circ} 51^{\prime} \mathrm{N}\right.$, $\left.99^{\circ} 53^{\prime} \mathrm{W}\right)$; iii) Naval Base $\left(16^{\circ} 51^{\prime} \mathrm{N}, 99^{\circ} 51^{\prime} \mathrm{W}\right)$; iv) Casa de Diaz Ordaz $\left(16^{\circ} 50^{\prime} \mathrm{N}, 9^{\circ} 51^{\prime} \mathrm{W}\right)$; and v) Centro de la Bahia $\left(16^{\circ} 49^{\prime} \mathrm{N}, 9^{\circ} 53^{\prime} \mathrm{W}\right)$. Van Dorn bottles were used to take samples of marine water (approximately $3 \mathrm{~L}$ in each sample) at 3 depths (1 m, $5 \mathrm{~m}$, and $10 \mathrm{~m})$ at each station. Water temperature, $\mathrm{pH}$ and salinity were measured in situ with a YSI probe.

Nutrient (nitrates, ammonium and phosphates) concentrations were determined in each sample following a standard colorimetric method (Hanna equip). Phytoplankton samples were fixed in concentrated Lugol's solution and cell quantification was made using the Utermöhl chamber sedimentation concentration method. ${ }^{10}$ Phytoplankton species were identified according to a specialized bibliography. ${ }^{11-16}$ Phytoplankton species distribution was established based on a review of published records for Mexico and other countries, and each species was classified as: (ES) estuarine, (NE) neritic, (AD) adiaphoric or (OC) oceanic.

The Olmstead-Tukey association test ${ }^{17}$ was applied to classify the phytoplankton species based on parameters of occurrence frequency and mean abundance: (D) dominant (abundant and frequent); (C) common (low abundance but frequent); (0) occasional (abundant
Correspondence: Juan Violante-González, Unidad Académica de Ecología Marina, Universidad Autónoma de Guerrero, Gran Vía Tropical No. 20, Fracc. Las Playas. C.P. 39390, Acapulco, Guerrero, México.

E.mail: viojuang@yahoo.com.mx

Key words: phytoplankton community, temporal variation, Acapulco bay, México.

Acknowledgements: this research was partially financed by the Conacyt and the State of Guerrero through the project "Estudio ecológico de la Bahía de Acapulco" (FOMIX 2008-01). It was also partially financed through the PROMEP (Programa de Mejoramiento del Profesorado) as part of the collaborative project "Calidad Ambiental y Desarrollo Sustentable" of which all the authors are participants. The authors wish to thank Aristeo Martínez Ramírez, Cuauhtémoc V. Gutiérrez García, Cuauhtémoc Valle Rodríguez Juan A. Meza García and Giovanni Moreno Díaz of the Marine Ecology Academic Unit (UAG) for their assistance with field and laboratory work

Received for publication: 27 October 2011. Accepted for publication: 4 December 2011.

This work is licensed under a Creative Commons Attribution NonCommercial 3.0 License (CC BYNC 3.0).

(C) Copyright A.A. Rojas-Herrera et al., 2012

Licensee PAGEPress srl, Italy

Microbiology Research 2012; 3:e4

doi:10.4081/mr.2012.e4

but low frequency); and (R) rare (low abundance and low frequency). A one-way ANOVA was applied to identify significant differences in monthly parameters (temperature, $\mathrm{pH}$ and salinity) and nutrient concentrations. When significant deviations from normality were identified, parameters and concentration data were $\log$-transformed $(\log x+1)$ to meet normality and homoscedasticity requirements. Any differences in phytoplankton abundance at the 3 tested depths were identified with a oneway ANOVA. A $\chi^{2}$ test was applied to identify significant differences in mean phytoplankton group abundance between months.

Community parameters included total number of species, total number of cells, the Shannon-Wiener $(\mathrm{H})$ diversity index, species evenness $(\mathrm{J})$ and the Berger-Parker Index (BPI) as a measure of numerical dominance. ${ }^{18,19}$ The qualitative Jaccard similarity index was used to evaluate similarity or difference in species composition between months. Student's $t$-test was applied to identify differences between community parameters, and correlations calculated using the Spearman's range coefficient $\left(r_{\mathrm{s}}\right)$ were applied to identify the parameters that determined observed species distribution and composition patterns. 


\section{Results}

Mean temperature at the sampling stations during the study period varied significantly from $25.8 \pm 0.56$ to $30.89 \pm 0.44^{\circ} \mathrm{C}$ (ANOVA, $\mathrm{F}=92.18, \mathrm{P}<0.05$ ), (Figure 1). Salinity varied from $32.31 \pm 0.07$ to $38 \pm 0.01$ psu (ANOVA, $\mathrm{F}=164.89, \mathrm{P}<0.05)$, while $\mathrm{pH}$ ranged from $7.82 \pm 0.21$ to $8.43 \pm 0.23$ (ANOVA, $\mathrm{F}=34.21$, $\mathrm{P}<0.05)$. Nutrient concentrations for the 3 tested nutrients varied significantly $(\mathrm{P}<0.05)$ during the study period: nitrate $\left(\mathrm{NO}_{3}^{-}\right)$and phosphate $\left(\mathrm{PO}_{4}=\right)$ concentrations increased from June to November, with highest levels in November; ammonium concentration $\left(\mathrm{NH}_{4}{ }^{+}\right)$ was highest in December (Figure 2).

Phytoplankton community taxonomic composition included a total of 87 species: 54 dinoflagellates (Dinophyta), 32 diatoms (Bacillariophyta) and one silicoflagellate (Heterokontophyta). Although the number of microalgal diatom species was relatively low, this group's total cell abundance represented more than $70 \%$ of the total cells collected during the sampling period. Phytoplankton species group differentiation showed that dinoflagellates dominated numerically from May to June, while diatoms increased constantly in abundance beginning in July and peaked between September and December (Figure 3). Monthly mean diatom species abundance was positively correlated with nitrate $\left(r_{s}=0.857, \mathrm{P}<0.05\right)$ and phosphate $\left(r_{\mathrm{s}}=0.786, \mathrm{P}<0.05\right)$ concentrations; dinoflagellate abundance exhibited no correlation.

Six species numerically dominated the community: 2 dinoflagellate species (Neoceratium belechii and Scrippsiella trochoidea) and 4 diatoms (Chaetoceros tetrastichon, Leptocylindrus danicus, Pseudosolenia calcaravis, and Pseudonitzschia sp.) (Table 1). These six species accounted for $66 \%$ of the total estimated cell counts in the samples. The dinoflagellates Dinophysis caudate, Neoceratium furca and Protoperidinium divergens were identified in all samples though none were numerically dominate. Based on phytoplankton species distribution, over $70 \%$ of the dinoflagellate and diatom species were classified as adiaphoric (i.e. they occur in neritic and oceanic areas) (Figure 4). The frequencyabundance graphic method indicated that $60 \%$ of the diatom species were dominant (i.e. abundant and frequent) while only $27 \%$ of dinoflagellate species were classified as dominant (Figure 5).

No differences in phytoplankton abundance (cell/L) were observed at the 3 sampled depths $(1,5$ and $10 \mathrm{~m}$ ) (ANOVA $\mathrm{F}=0.283, \mathrm{P}>0.05$ ), therefore all abundance data were pooled for subsequent analyses. Monthly mean abundance varied $\left(\chi^{2}\right.$ test, $\left.P<0.05\right)$ between sam- pling stations, with stations 1 (Club de Yates) and 4 (Casa de Diaz Ordaz) each having the highest mean values for three months, although not in the same months (Figure 6). Mean abundance was highest at station 1 from September to November, but highest at station 4 in May, June and September (Figure 6).

Species richness varied significantly $(t-$ test $=6.42, \mathrm{P}<0.05)$ from 17 species (May) to 49 species (July), while monthly total abundance ranged from 76,266 cell/L (July) to 709,000 cell/L (December), exhibiting significant increases in later months ( $t$-test $=3.32$, $\mathrm{P}<0.05$ ) (Table 1). Shannon-Wiener diversity index values ranged from 1.40 to 3.92 and evenness from 0.27 to 0.70 ; both parameters

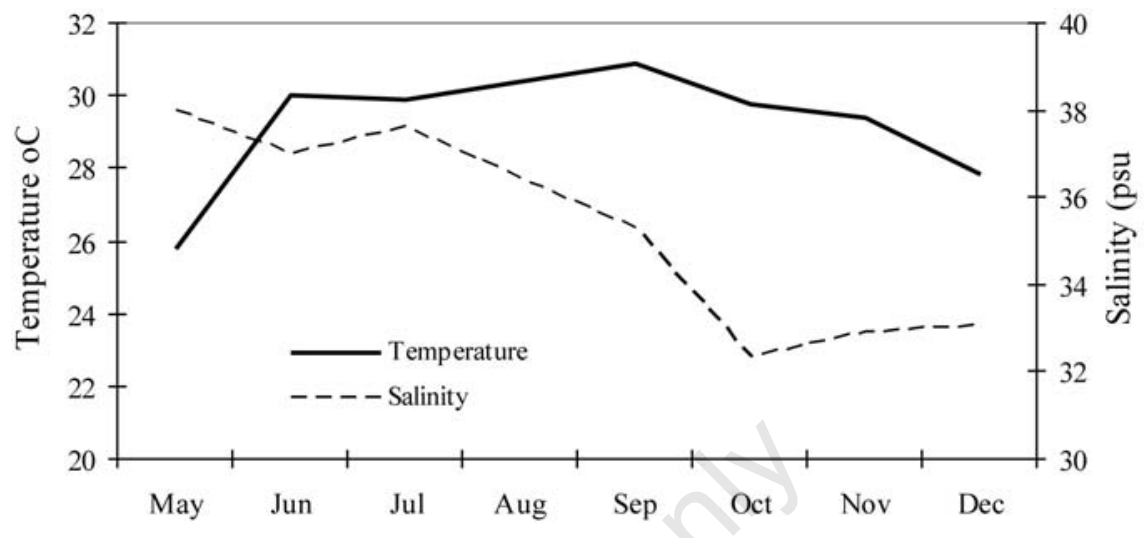

Figure 1. Monthly temperature and salinity values in Acapulco Bay, Mexico, between May-December.

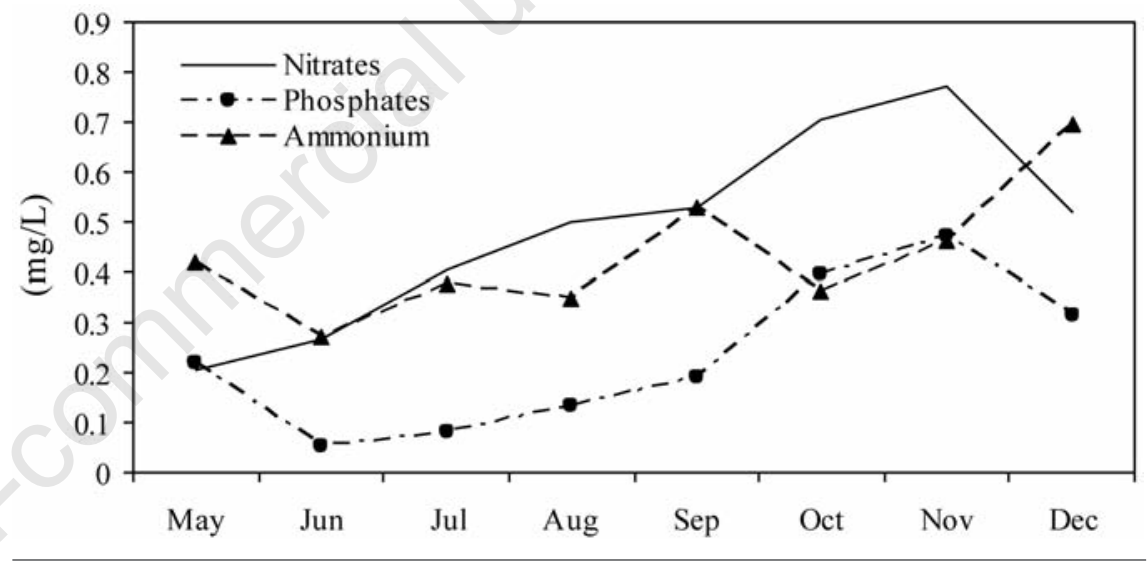

Figure 2. Monthly nutrient concentrations (mg/L) in Acapulco Bay, Mexico.

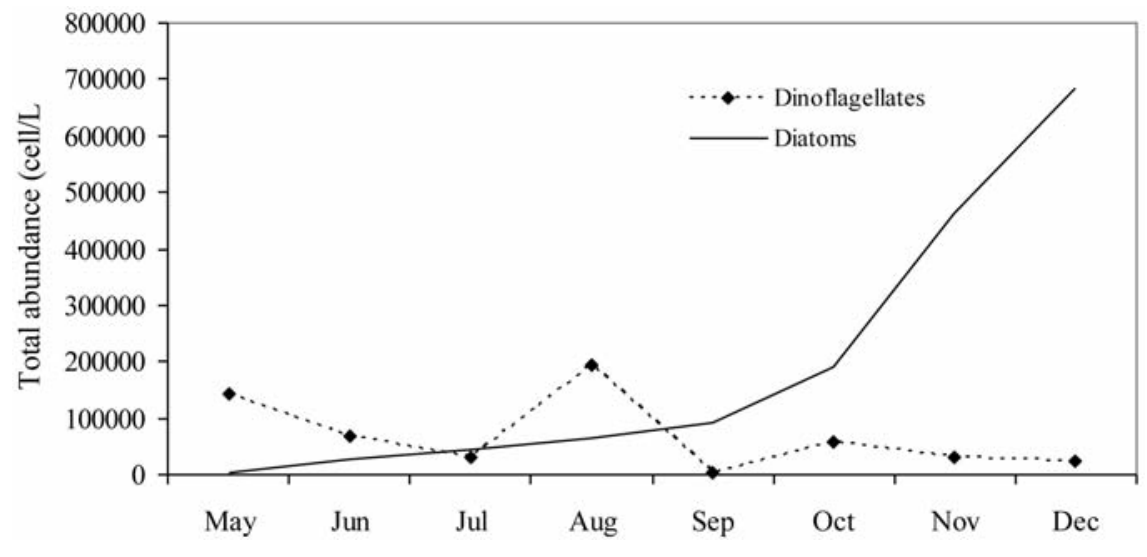

Figure 3. Temporal variation of dinoflagellate and diatom groups in Acapulco Bay, Mexico. 
varied significantly between months ( $t$ test $=7.85 ; \quad 10.54, \quad \mathrm{P}<0.05, \quad$ respectively). Diversity index values were significantly higher in July (3.92) and October (3.23) and correlated positively with their respective evenness values $\left(r_{\mathrm{s}}=0.97, \mathrm{P}<0.05\right)$. Similarity in species composition was low $(<10 \%)$ during most months, but increased to $50 \%$ in November and December (Figure 7).

\section{Discussion}

Water temperature was almost constant from June to December, varying only $3^{\circ} \mathrm{C}$ most months (Figure 1), whereas salinity decreased significantly during the same period (Figure 1). Temperature fluctuations are not as extreme in tropical marine areas as those seen in temperate or cold latitudes, suggesting that this environmental parameter is not very informative in terms of species composition in tropical phytoplankton communities. ${ }^{9}$ The fluctuations in salinity values that were observed can be attributed to freshwater flowing into the bay during the rainy season (June to November). Salinity is known to have a notable effect on the structuring of phytoplankton communities, particularly in estuarine and coastal environments. ${ }^{8,9,20,21}$

The constant increase in nitrate and phosphate concentrations between June and November can also be attributed to rainfall runoff during this season. ${ }^{7}$ Sewage, as well as huge quantities of garbage and other solid materials from the Acapulco urban area discharge directly into the bay, contributing to higher nutrient concentrations and consequent population growth in several phytoplankton species. ${ }^{7,9}$

The dinoflagellates (54 species) dominated the phytoplankton community in Acapulco Bay (Table 2), although total abundance of the group was significantly lower than that of the diatoms. This contrasts with patterns reported in other studies of phytoplankton composition carried out at tropical latitudes in which diatoms dominate in terms of species number. ${ }^{7-9,22}$ Phytoplankton are considered to be good indicators of water conditions in neritic and oceanic masses. ${ }^{23,24}$ Dinoflagellates are better adapted to the oceanic environment, while diatoms are more adapted to coastal environments. ${ }^{8,23}$ Therefore, our results suggest that environmental conditions in Acapulco Bay change during the year in response to variations in several environmental parameters. Changes in the bay's water masses are probably reflected in the traits presented by the phytoplankton species inhabiting it; for example, more than $70 \%$ of the dinoflagellate and diatom species recorded in the present study are adapted to neritic or oceanic environments, that is they are classified as adiaphoric species. ${ }^{8}$ (Figure 4 ).

Phytoplankton abundance (cel//L) did not vary significantly at the 3 depths studied, probably because diatoms dominated numerically at all depths. This numeric dominance occurs because diatoms adapt to living in the entire

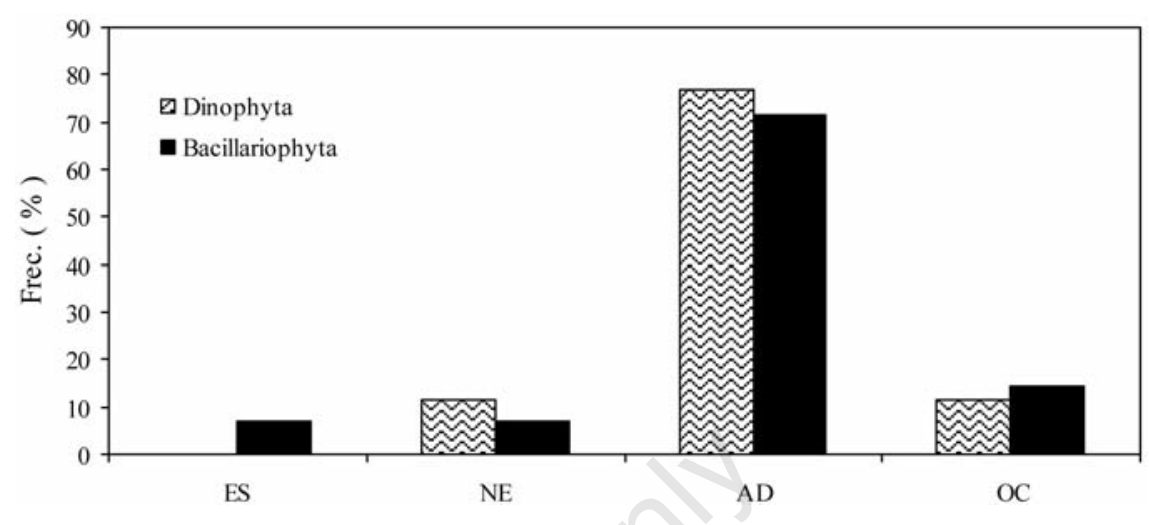

Figure 4. Frequency distribution of phytoplankton species from Acapulco Bay, Mexico, based on origin: $\mathrm{ES}$, estuarine; $\mathrm{NE}$, neritic; $\mathrm{AD}$, adiaphoric; $\mathrm{OC}$, oceanic.

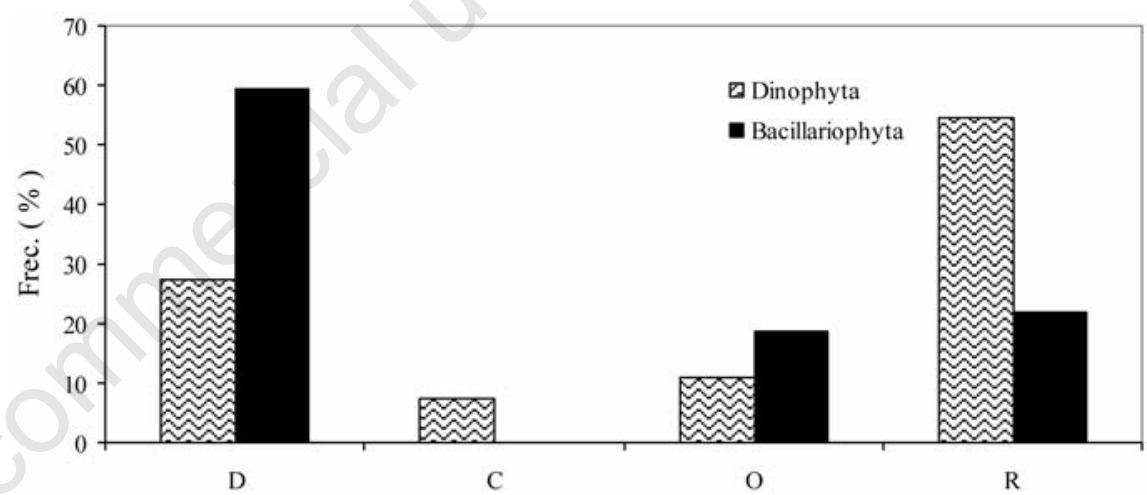

Figure 5. Phytoplankton species classification based on the frequency-abundance graphic method (Olmstead-Tukey association test). D, dominant; C, common; O, occasional; $R$, rare.

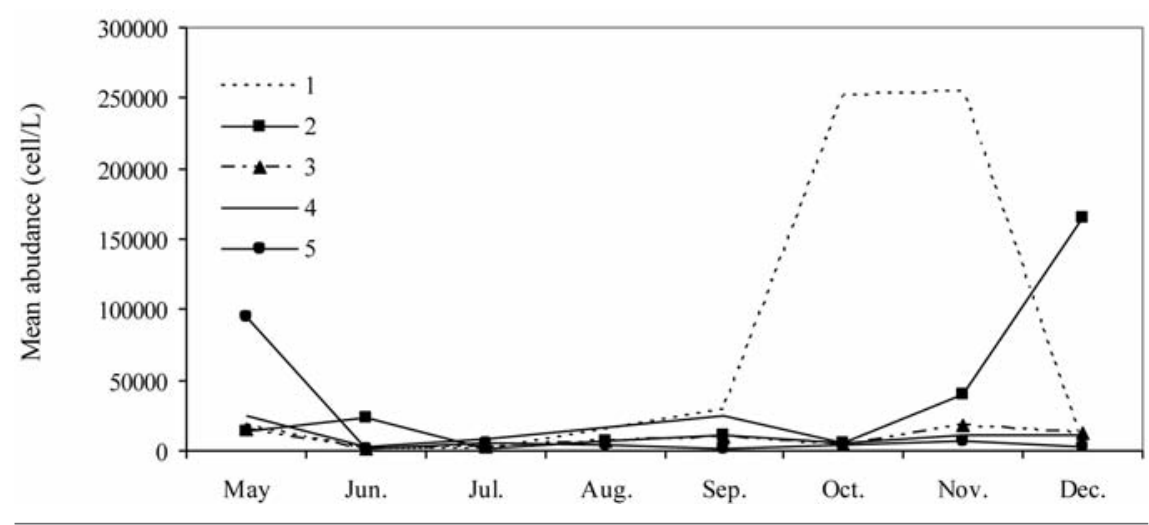

Figure 6. Temporal variation in mean abundance (cell/L) per sampling station: 1) Club de Yates; 2) Islote del Morro; 3) Base Naval; 4) Casa de Diaz Ordaz; 5) Centro de la Bahía. 
and Casa de Diaz Ordaz (station 4), as a result of increased nutrient concentration in these areas.

Different species dominated numerically in each month, indicating wide variability in species composition over time. The dinoflagellate $N$. belechii dominated at the end of the dry season and beginning of the rainy season (May to June), while different diatom species dominated during the rainy season (Table 1). Changes in phytoplankton community structure have been associated with small changes in water temperature ${ }^{9,22}$ or with the different strategies used by phytoplankton groups to absorb available nutrients in the water column. ${ }^{6}$ The higher abundance of some dinoflagellate species in June and August may, therefore, be associated with warmer temperatures during these months since high temperatures favor growth in some dinoflagellate populations (Figure 1). In contrast, diatoms respond more rapidly to increases in available nutrient

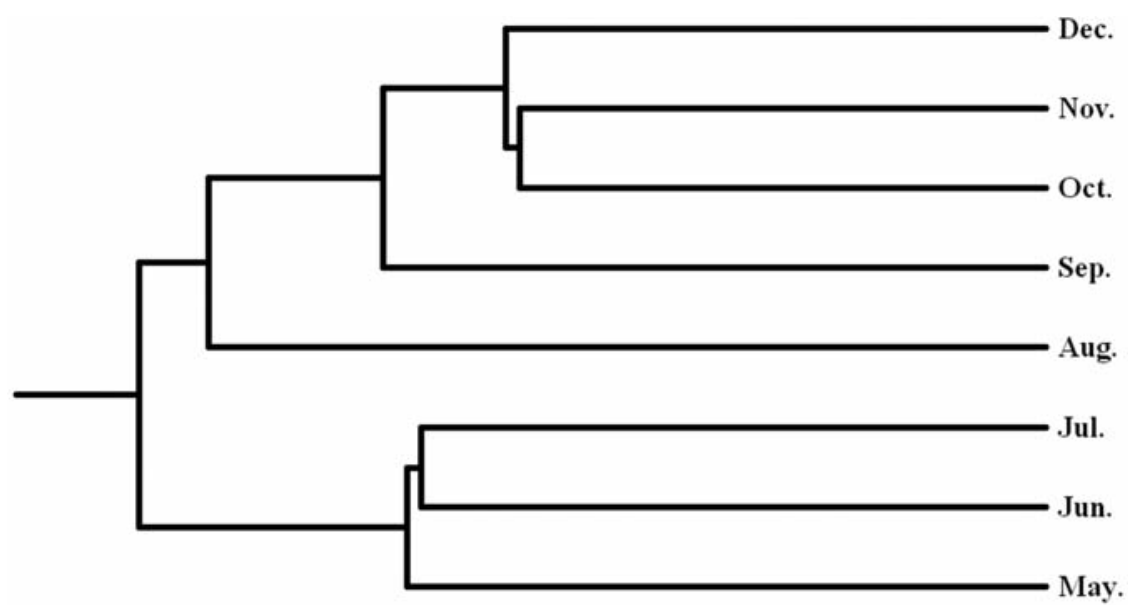

0. \% Similarity

50.

100

Figure 7. Similarity percentages for monthly phytoplankton samples in Acapulco Bay, Mexico.

Table 1. Characteristics of the phytoplankton community in Acapulco Bay, Mexico. Dino, dinoflagellates; Diat, diatoms; BPI, BergerParker index; H, Shannon-Wiener diversity index; J, evenness.

\begin{tabular}{lcccccrrrr} 
Month & $\begin{array}{c}\text { N. of } \\
\text { species }\end{array}$ & $\begin{array}{c}\text { Dino. } \\
\text { N. cell }\end{array}$ & $\begin{array}{c}\text { Diat. } \\
\text { N. cell }\end{array}$ & Total cell & Dominant specie & BPI & H' \\
May & 17 & 142173.3 & 2133.3 & 144306.6 & Neoceratium belechii & 0.76 & 1.45 & 0.36 \\
June & 28 & 66400.1 & 28400.2 & 94800.3 & Neoceratium belechii & 0.38 & 2.99 & 0.62 \\
\hline July & 49 & 31466.9 & 44800 & 76266.9 & Chaetoceros tetraschiton & 0.25 & 3.92 & 0.70 \\
Aug. & 16 & 195399.9 & 63266.6 & 258666.5 & Scrippsiella trochoidea & 0.57 & 2.11 & 0.53 \\
\hline Sep. & 14 & 4266.7 & 92533.3 & 96800 & Pseudosolenia calcar-avis & 0.22 & 1.99 & 0.52 \\
Oct. & 42 & 58600.1 & 189733.4 & 248333.5 & Pseudonitzschia sp. & 0.27 & 3.23 & 0.60 \\
\hline Nov. & 37 & 31400.3 & 461399.9 & 492800.2 & Leptocylindrus danicus & 0.42 & 2.84 & 0.55 \\
Dec. & 35 & 24000.1 & 685000 & 709000.1 & Leptocylindrus danicus & 0.81 & 1.40 & 0.27 \\
\hline
\end{tabular}

Table 2. Composition and abundance (cell/L) of the phytoplankton community in Acapulco Bay, Mexico.

\begin{tabular}{|c|c|c|c|c|c|c|c|c|}
\hline Specie & May & June & July & Aug. & Sep. & Oct. & Nov. & Dec. \\
\hline \multicolumn{9}{|l|}{ Dinophyta } \\
\hline Akasiwo sanguinea $^{2}$ (D) & & & & 1933.3 & & 1933.3 & 1000 & 200 \\
\hline Alexandrium catenella ${ }^{2(\mathrm{R})}$ & & & & & & 133.3 & & 66.7 \\
\hline Balechina coerulea $^{3(\mathrm{R})}$ & & & & 666.7 & & & & \\
\hline Dinophysis caudata ${ }^{3}$ (D) & 1333.3 & 1933.3 & 5333.3 & 17133.3 & 266.7 & 3066.7 & 733.3 & 933.3 \\
\hline Dinophysis doryphora ${ }^{3(\mathrm{C})}$ & & & & & & 733.3 & & 466.7 \\
\hline Dinophysis odiosa ${ }^{3(\mathrm{R})}$ & & & 133.3 & & & & & \\
\hline Dinophysis rudgei $3(\mathrm{R})$ & & & & & & 266.7 & & \\
\hline Gonyaulax spinifera $^{3}$ (D) & & 1000 & 200 & & & 8400 & 600 & 2466.7 \\
\hline Gymnodinium catenatum ${ }^{2}$ (D) & 3800 & 1266.7 & 133.3 & 3133.3 & & 12466.7 & 17266.7 & 1933.3 \\
\hline Lingulodinium polyedrum ${ }^{2}(0)$ & & & & 2600 & & & & \\
\hline Neoceratium azoricum $3(\mathrm{R})$ & & 266.7 & 266.7 & & & & & \\
\hline Neoceratium belechii ${ }^{3}$ (D) & 109640 & 35666.7 & 133.3 & & 600 & 800 & 466.7 & 66.7 \\
\hline Neoceratium belechii f. longum ${ }^{3}$ (D) & 10400 & 466.7 & 466.7 & & & & & \\
\hline Neoceratium biceps $3(\mathrm{R})$ & & 133.3 & 200 & & & & & \\
\hline Neoceratium breve $4(\mathrm{R})$ & & 1066.7 & & & & & & \\
\hline Neoceratium breve var. parallelum $4(\mathrm{R})$ & & 600 & & & 200 & 333.3 & 266.7 & \\
\hline Neoceratium candelabrum ${ }^{3(\mathrm{R})}$ & & 933.3 & & & & & & \\
\hline Neoceratium candelabrum var. depressum ${ }^{3}$ (R) & 200 & & 133.3 & & & & 400 & \\
\hline
\end{tabular}


Table 2. Continued from previous page.

\begin{tabular}{|c|c|c|c|c|c|c|c|c|}
\hline Specie & May & June & July & Aug. & Sep. & Oct. & Nov. & Dec. \\
\hline Neoceratium carriense $3(\mathrm{R})$ & & & & & 600 & & & \\
\hline Neoceratium deflexum ${ }^{3}(0)$ & 266.7 & 1866.7 & & & & 66.7 & & \\
\hline Neoceratium furca ${ }^{2}$ (D) & 10200 & 5600 & 5066.7 & 7133.3 & 2333.3 & 16600 & 2666.7 & 5266.7 \\
\hline Neoceratium fusus 2 (D) & & 3266.7 & 66.7 & & & 1600 & 1866.7 & 2933.3 \\
\hline Neoceratium lunula ${ }^{3(\mathrm{R})}$ & 200 & & & & & & & \\
\hline Neoceratium macroceros 3 (C) & & & 466.7 & & & 200 & 733.3 & \\
\hline Neoceratium praelongum 3 (R) & & & 66.7 & & & & & \\
\hline Neoceratium ranipes $4(\mathrm{R})$ & 66.7 & & & & & & & \\
\hline Neoceratium teres $3(\mathrm{R})$ & & & & & & & 66.7 & \\
\hline Neoceratium tripos 3 (D) & 2266.7 & & 133.3 & & & & & \\
\hline Nocticula scintillans ${ }^{3}(\mathrm{R})$ & & & 666.7 & & & & 133.3 & \\
\hline Ornithocercus heterophorus 4 (C) & & & 66.7 & & & & 1000 & \\
\hline Ornithocercus magnificus ${ }^{4}(\mathrm{R})$ & & & 133.3 & & & & & \\
\hline Ornithocercus quadratus ${ }^{3(\mathrm{R})}$ & & & 600 & & & & & \\
\hline Ornithocercus sp. ${ }^{\mathrm{R})}$ & & & & & & 600 & & \\
\hline Ornithocercus steinii ${ }^{4}(\mathrm{R})$ & & & 200 & & & & & 66.7 \\
\hline Ornithocercus thumii ${ }^{3(\mathrm{R})}$ & & & 66.7 & & & & & \\
\hline Oxytoxum parvum $3(\mathrm{R})$ & & & 200 & & & & & \\
\hline Podolampas bipes ${ }^{3(\mathrm{R})}$ & 133.3 & & 133.3 & & & & & \\
\hline Prorocentrum compressum 3 (R) & & & & & & & 66.7 & \\
\hline Prorocentrum gracile 2 (D) & & 733.3 & 1266.7 & & & 1800 & 66.7 & 133.3 \\
\hline Prorocentrum micans ${ }^{3}$ (D) & & & & & & 4000 & 1066.7 & 2200 \\
\hline Protoperidinium claudicans 3 (C) & & 133.3 & 400 & & & 400 & & 266.7 \\
\hline Protoperidinium conicoides ${ }^{3(\mathrm{D})}$ & & & 66.7 & & & 666.7 & 866.7 & 2200 \\
\hline Protoperidinium conicum $^{3}(\mathrm{R})$ & & & 266.7 & & & & & 66.7 \\
\hline Protoperidinium depressum 3 (D) & 133.3 & 11000 & 266.7 & 1200 & & & & \\
\hline Protoperidinium divergens ${ }^{3}$ (D) & 3400 & 133.3 & 466.7 & 14600 & 866.7 & 2066.7 & 1600 & 2733.3 \\
\hline Protoperidinium latispinum 3 (R) & & 66.7 & 66.7 & & & & & \\
\hline Protoperidinium pellucidum ${ }^{3(0)}$ & & & 12466.7 & & & & & \\
\hline Protoperidinium pentagonum ${ }^{3}(\mathrm{R})$ & & 66.7 & & & & & & \\
\hline Protoperidinium pyriforme 3 (D) & & & & & & 1533.3 & 466.7 & 66.7 \\
\hline Protoperidinium robustum ${ }^{3(0)}$ & & & & 400 & & & & 1933.3 \\
\hline Protoperidinium sp. ${ }^{(\mathrm{C})}$ & & & 800 & 266.7 & & & 66.7 & \\
\hline Protoperidinium steinii ${ }^{3}(\mathrm{R})$ & 133.3 & 200 & & & & & & \\
\hline Pyrodinium bahamense var. compressum ${ }^{3}(\mathrm{R})$ & & & & & & 200 & & \\
\hline Scrippsiella trochoidea ${ }^{3(0)}$ & & & & 146333.3 & & & & \\
\hline Subtotal & 142173.3 & 66400.1 & 31466.9 & 195399.9 & 4266.7 & 58600.1 & 31400.3 & 24000.1 \\
\hline Bacillariophyta & & & & & & & & \\
\hline Chaetoceros affinis ${ }^{3}$ (D) & & & & & 1000 & & & \\
\hline Chaetoceros constrictus ${ }^{3}(0)$ & & & 7666.7 & & & & & \\
\hline Chaetoceros curvisetus ${ }^{3}$ (D) & & & 333.3 & & 2333.3 & 266.7 & 9600 & \\
\hline Chaetoceros decipiens ${ }^{3}$ (D) & & & 533.3 & & 4400 & 933.3 & 5000 & \\
\hline Chaetoceros sp. $(0)$ & & 4466.7 & 4400 & & & & & \\
\hline Chaetoceros tetrastichon 3 (D) & & 19800 & 18866.7 & & & & & \\
\hline Coscinodiscus concinnus ${ }^{2}(\mathrm{R})$ & & & & & 533.3 & & & \\
\hline Coscinodiscus sp. ${ }^{(\mathrm{D})}$ & 533.3 & 66.7 & 733.3 & & 133.3 & 10333.3 & 5600 & 2733.3 \\
\hline Cylindrotheeca closterium 4 (R) & & & & & & 66.7 & & \\
\hline Ditylum brightwelli $\left.{ }^{3}(\mathrm{D})\right)$ & & & 2733.3 & & & 3400 & 4733.3 & 2333.3 \\
\hline Eucampia zoodiacus ${ }^{3}$ (D) & & & & & & 66.7 & & 1933.3 \\
\hline Guinardia flaccida $^{3}$ (D) & & & & & & 2666.7 & 10600 & 66.7 \\
\hline Guinardia striata $^{3}$ (D) & & & & 1133.3 & & 200 & 1066.7 & 19466.7 \\
\hline Gyrosigma peisonis $3(0)$ & & & 1866.7 & & & & & \\
\hline Leptocylindrus danicus 3 (D) & & & & 52600 & & 7466.7 & 204533.3 & 576066.7 \\
\hline Melosira granulata ${ }^{1(\mathrm{D})}$ & & & & & & 83800 & 121200 & \\
\hline Navicula sp. ${ }^{(0)}$ & & & 133.3 & & & & 866.7 & 1200 \\
\hline Nitzschia closterium ${ }^{3}(\mathrm{R})$ & & & & & & & & 66.7 \\
\hline Nitzschia sigma ${ }^{1(\mathrm{R})}$ & & & 66.7 & & & & & \\
\hline Nitzschia sp. (D) & 1466.7 & 200 & 1333.3 & 1333.3 & & 2733.3 & 15666.7 & 10800 \\
\hline Pleurosigma decorum ${ }^{3}$ (D) & & & 66.7 & & & 1266.7 & 4066.7 & 2266.7 \\
\hline Pleurosigma distinguendum 3 (D) & & 266.7 & & 2800 & & 200 & 600 & 10533.3 \\
\hline Pseudonitzschia delicatissima ${ }^{3(0)}$ & & & 1400 & & & & & 2066.7 \\
\hline Pseudonitzschia sp. (D) & & 3066.7 & 400 & & 55200 & 66266.7 & 41133.3 & 35333.3 \\
\hline Pseudosolenia calcar-avis 2 (D) & & & 600 & & 21466.7 & 133.3 & 4533.3 & 10000 \\
\hline Rhizosolenia hebetata 3 (D) & & & & 5400 & & 2533.3 & 7733.3 & \\
\hline Rhizosolenia imbricata ${ }^{3(\mathrm{D})}$ & & & & & & 2666.7 & 21933.3 & 8933.3 \\
\hline
\end{tabular}

To be continued on next page 
Table 2. Continued from previous page.

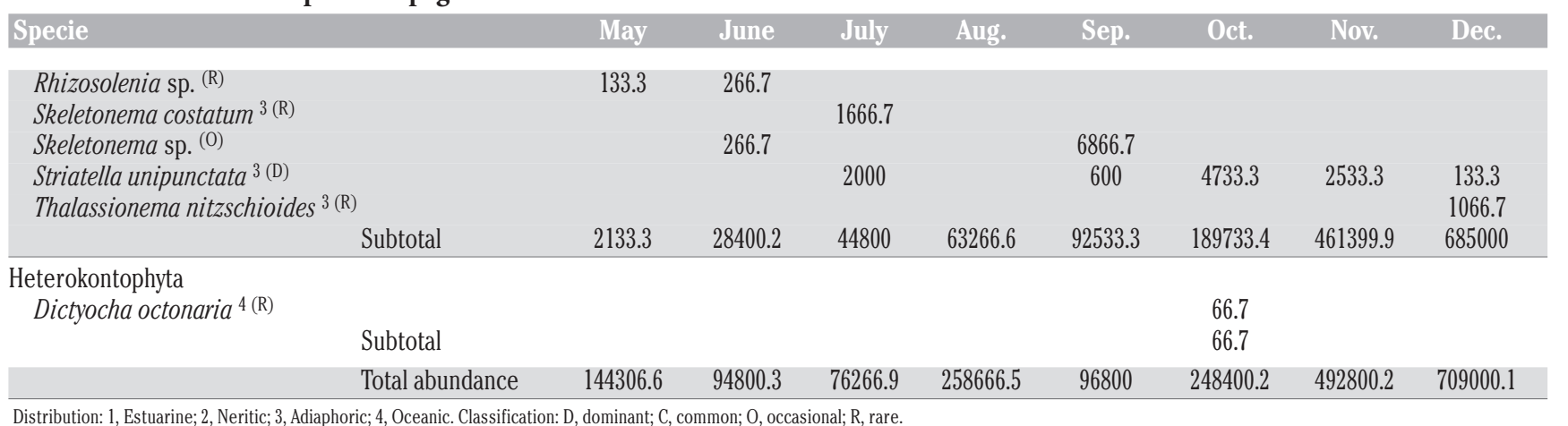

concentration, ${ }^{25}$ resulting in faster population growth than in dinoflagellates and possibly explaining their higher counts during the rainy season.

At least 8 of the 54 identified dinoflagellate species (Alexandrium catenella, Dinophysis caudata, Gymnodinium catenatum, G. sanguinium, Neoceratium furca, $N$. fusus, $N$. tripos and Pyrodinium bahamense var. compressum) have been reported in $\mathrm{HAB}$, or red tides, in other locations in Mexico. ${ }^{26,27}$ of these, only $D$. caudata and $N$. furca were found to be abundant and frequent (dominant) during the sampling months. Pyrodinium bahamense var. compressum was also identified in the present study but it was a rare species with low abundance collected only in October (Table 2); it was, however, the cause of an HAB event in Acapulco Bay in July 2010, some months after the final sampling carried out for the present study.

The pattern of species distribution of the phytoplankton community in Acapulco Bay was similar to patterns reported for other marine or estuarine communities. Community structure was determined by a low number of dominant species (2 dinoflagellates and 4 diatoms) which contributed over $60 \%$ of total abundance, and a high number of occasional and rare species $(>50 \%)$ (Figure 5 ). Total richness (87 species) in the study area was within the species number range reported for other locations in Mexico ${ }^{26}$ and other countries with similar climatological conditions. ${ }^{7,8,22}$ The diversity values recorded here are similar to those reported for other locations in the tropical Pacific. ${ }^{8}$ The higher diversity values recorded in the months of July (3.2) and October (3.23) can be attributed to the fact that some species' dominance diminished, whereas in other months these species' abundances (and therefore their dominance) remained fairly constant (evenness $\geq 0.60$, Table 1). The low similarity values observed here (Figure 7) suggest the possibility that species composition differed between months in response to variability in environmental conditions over time.
Overall, the results indicate that phytoplankton species composition and abundance in Acapulco Bay varied spatially and temporally due to variations in environmental conditions. These environmental variations were caused by changes in nutrient concentrations which were a result of differences in rainfall between the local dry and rainy seasons. Higher nutrient concentrations promoted population growth in dinoflagellate or diatom species at different time points during the year.

\section{References}

1. Silver W, Platt T. Energy flux in the pelagic ecosystem: A time-dependent equation. Limnol Oceanogr 1978;23:813-6.

2. Steel JH. Patchiness. In: DH Cushing, JJ Walsh (eds.) The ecology of the seas. Blackwell Scientific Publications, Londres, Gran Bretaña, 1976, pp 98-115.

3. Bauman AG, Burt JA, Feary DA, et al. Tropical harmful algal blooms: an emerging threat to coral reef communities? Mar Pollut Bull 2010;60:2117-22.

4. Vargas-Montero M, Bustamante EF, Guzmán JC, Vargas JC. Florecimientos de dinoflagelados nocivos en la costa Pacífica de Costa Rica. Hidrobiol 2008;18:15-23.

5. Zingone A, Oksfeldt EH. The diversity of harmful algal blooms: A challenge for science and management. Ocean Coast Manag 2000;43:725-48.

6. Langlois GW, Smith P. Phytoplankton In: US Geological Survey. Biology and Ecological Niches in the Gulf of the Farallones. Reston, Virginia, 2001, pp 32-5.

7. Moreira A, Seisdedo MI, Leal S, et al. Composición y abundancia del fitoplancton de la Bahía de Cienfuegos, Cuba. Rev Invest Mar 2007;28:97-109.

8. Peña V, Pinilla GA. Composición, distribución y abundancia de la comunidad fitoplanctónica de la ensenada de Utría, Pacífico colombiano. Rev Biol Mar Oceanogr 2002;37:67-81.
9. Varona-Cordero F, Gutiérrez-Mendieta FJ. Composición estacional del fitoplancton de dos lagunas del Pacífico tropical. Hidrobiol 2006;16:159-74.

10. Lund JW, Kipling C, Lecren ED. The inverted microscope method of estimating algal numbers and the statistical basis of estimations by counting. Hidrobiol 1958;11:110.

11. Hernández-Becerril DU. Morfología y taxonomía de algunas de las especies de diatomeas del género Coscinodiscus de las costas del Pacífico mexicano. Rev Biol Trop 2000;48:7-18.

12. Hernández-Becerril DU. Diversidad del fitoplancton marino de México. Un acercamiento actual. Cap. 1. In: MT BarreiroGüemes, ME Meave del Castillo, M Signoret-Poillon, MG Figueroa-Torres (eds.) Planctonología Mexicana. Sociedad Mexicana de Planctonología, AC México, 2003, pp 1-18.

13. Licea S, Moreno JL, Santoyo H, Figueroa G. Dinoflagelados del Golfo de California. México. Universidad Autónoma de Baja California Sur, México, 1995, p 165.

14. Moreno JL, Licea S, Santoyo H. Diatomeas del Golfo de California. México. Universidad Autónoma de Baja California Sur, México, 1995, p 273.

15. Round FE, Crawford RM, Mann DG. The Diatoms. Biology and morphology of the genera. Cambridge University Press, 1990, p 747.

16. Tomas CR. Identifying Marine Phyto-plankton. Academic Press, San Diego, USA, 1997, p 858.

17. Sokal RR, Rohlf FJ. Biometry, 2nd ed. WH Freeman and Company, San Francisco, California, 1998, p 859.

18. Krebs CJ. Ecological methodology. AddisonWelsey Educational Publishers, Inc. Boston, Massachusetts, 1999, 654 pp.

19. Magurran A. Ecological diversity and its measurement. Princeton University Press, Princeton, New Jersey, 1991, p 178.

20. Lassen MF, Bramm ME, Richardson K, et al. Phytoplankton community composition 
and size distribution in the Langat River Estuary, Malaysia. Estuar 2004;27:716-27.

21. Troccoli LG, Herrera-Siveira JA, Comín F. Structural variations of phytoplankton in the coastal seas of Yucatán, México. Hidrobiol 2004;519:85-102.

22. Ochoa N, Tarazona J. Variabilidad temporal de pequeña escala en el fitoplancton de Bahía Independencia, Pisco, Perú. Rev Per Biol 2003;10:59-66.

23 Castillo F. Fitoplancton del Pacífico colombiano como indicador de masas de agua. Erfen IV. Biol Pesq 1984;13:67-70.
24. Castillo F, Vidal A. Fitoplancton del Pacífico colombiano como indicadores de masas de agua. Fase CIOH, Cartagena, 1982, pp 1-57.

25. Örnólfsdóttir EB, Lumsden E, Pinckney JL. Phytoplankton community growth-rate response to nutrient pulses in a shallow turbid estuary, Galveston Bay, Texas. J Plank Res 2004;26:325-39.

26. Cabrera-Mancilla E, Ramírez-Camarena $\mathrm{C}$, Muñoz-Cabrera L, Monreal-Prado A. Primer registro de Gymnodinium catenatum Graham (Gymnodiniaceae) como causante de marea roja en la Bahía de Acapulco, Gro.
México. In: E Ríos-Jara, E Juárez-Carillo, M Pérez-Peña, E López-Uriarte, EG RoblesJarero, DU Hernández-Becerril, M SilvaBriano (eds.) Estudios sobre plancton en México y el Caribe. Sociedad Mexicana de Planctología y Universidad de Guadalajara, 2000, pp 85-6.

27. Gárate-Lizárraga I, Pérez-Cruz B, DíazOrtíz J, Band-Schmidt C J. Microalgas y biotoxinas marinas en las costas mexicanas. Conver 2008;9:22-6. 